\title{
ANÁLISE ECONÔMICA DO DIREITO CIVIL: IMPLICAÇÕES PARA O DESENVOLVIMENTO HUMANO E REDUÇÃO DAS DESIGUALDADES
}

\author{
Edilene Lôbo ${ }^{1}$ \\ Suzana Oliveira Marques Brêtas ${ }^{2}$
}

\begin{abstract}
RESUMO
A análise econômica do direito de propriedade não pode se afastar da conformação social que deu a Constituição, tanto que a omissão na adoção de políticas públicas que lhe permitam se efetivar pode ser corrigida pelo Judiciário. A busca de mínimos existenciais de acesso à moradia como direito social para segurança e identidade não se compadece do quadro vivido, impondo releitura para superação da onda neoliberal que o identifica como individual e inviolável. A metodologia utilizada, apoiada no referente de justiça social sob os influxos da dignidade humana no paradigma democrático, implicou revisão bibliográfica, exame da legislação e da jurisprudência.
\end{abstract}

PALAVRAS-ChAVE: Análise econômica; Direito Civil; Direito de propriedade; Desenvolvimento humano; Redução das desigualdades.

\section{CIVIL LAW’S ECONOMIC ANALYSIS: EFFECTS ON HUMAN-DEVELOPMENT AND INEQUALITIES ABATEMENT}

\begin{abstract}
Property rights economic analysis cannot stray from the socialist shape constitutionally given. Proof of that is the judicial correction possibility of public-policies absence to put it into effect. The search for housing-access "existential-minimums", in order to obtain safety and identity, don't tolerate the current state-of-things, demanding the topic's new look to overcome the neoliberal-wave identifying it as individual and inviolable. The utilized methodology, anchored on the Justice referential influenced by human-dignity in the democratic-paradigm, comprised bibliographical revision and law and jurisprudence exam.
\end{abstract}

KEY-WORDS: Economic Analysis. Civil-Law; Property Rights; Human-Development; Inequalities-Abatement.

\section{INTRODUÇÃO}

A análise da ciência jurídica pode sofrer alterações ao longo do tempo, em razão de múltiplos fatores como globalização, informatização, ideologias, avanços e retrocessos das relações humanas, estas sempre complexas, sem dúvida. Nos últimos tempos, as sociedades vivenciaram grandes transformações políticas, econômicas, tecnológicas e culturais, que

\footnotetext{
${ }^{1}$ Doutora em Direito Processual pela PUCMINAS. Mestre em Direito Administrativo pela UFMG. Especialista em Processo Penal pela Universidade Castilla La-Mancha. Professora do Mestrado e da Graduação em Direito da Universidade de Itaúna/MG. Advogada.

${ }^{2}$ Doutora em Direito Privado. Mestre em Educação. Professora da Graduação da Universidade de Itaúna. Advogada.
} 
também influenciaram a forma de se analisar e interpretar o ordenamento jurídico.

No que interessa ao presente trabalho, como objetivo central, impõe assinalar a repercussão da análise econômica do direito, em especial o de propriedade, a ser filtrado por políticas públicas buscando mínimos existenciais, sob os influxos da dignidade da pessoa humana no paradigma democrático, à busca da concretização do acesso à justiça social - este também seu referente teórico.

Entretanto, a questão revela-se complexa e atual, justificando a pesquisa, eis que é necessário compreender o que é a ciência jurídica e seu campo originário de aplicação, a ciência econômica e seu objeto, e a razão de ser da vida em coletividade, para que se dê sentido à análise econômica do direito e suas implicações no cotidiano das pessoas, em especial as menos favorecidas. Enfim, é também seu objetivo ressaltar a importância dos mínimos sociais para garantia de uma vida boa, rumo à ruptura das desigualdades e do desenvolvimento humano.

Este trabalho tem como objeto, por fim, a iniciação no exame desse método interpretativo, enfatizando a pesquisa na evolução da propriedade privada imobiliária, sem descuidar de seu acesso como direito social elementar capaz de propiciar moradia, segurança e dignidade.

A metodologia utilizada para se chegar às conclusões apresentadas é predominantemente dedutivo-hipotética, com estudo da legislação, da literatura e da jurisprudência. Com isso se pode ofertar a necessária viragem na interpretação do direito de propriedade imobiliária a par das políticas públicas que o possam materializar pela garantia da posse como mínimo existencial.

\section{DIREITO, ECONOMIA E ANÁLISE ECONÔMICA}

O direito é ciência social aplicada que visa regulamentar a vida em sociedade e difere da norma moral em razão de seu caráter sancionatório, embora ambos sejam normas de comportamento. Contudo, a norma jurídica sempre contem definições e elementos que são de outras ciências, como a economia, a matemática, a antropologia, dentre outras. A norma jurídica e a decisão judicial (aqui será chamada de norma jurídica do caso concreto) podem produzir efeitos e consequências que extrapolam o campo jurídico e geram efeitos em outras ciências, como a economia.

Raoul Charles Van Caenegem, tratando dos elementos da história do direito, citou 
Theodore Frank Thomas Plucknett, para quem são fatores componentes dessa ciência os costumes, a legislação e os precedentes, de origem romano-canônica. Além desses, é claro, os fatores sociais, que configuram disputas de ordem política, socioeconômica e intelectual (CAENEGEM, 2000, p. 253).

Focando nesses últimos, a análise econômica do direito é metodologia que tem por objetivo examinar a norma jurídica e a sua repercussão social e econômica, extrapolando o mundo das regras, notadamente incursionando pela sociologia.

É fato que a visão econômica do direito sempre existiu, bastando lembrar o famoso caso da montadora Ford, ocorrido nos Estados Unidos no século $\mathrm{XX}^{3}$. Tal prática é ainda comum e usual, eis que mesmo conscientes que estão produzindo bens com alguma falha técnica ou alto grau de poluentes, empresas os lançam no mercado. Certamente o fazem após aferirem se é interessante investir em tecnologia e consertar o produto ou arcar com o custo de eventuais indenizações decorrentes de ações judiciais. Aqui o julgamento não é ético ou moral, mas meramente de custo jurídico versus benefício econômico de determinada decisão ou comportamento.

Ivo Gico Jr. faz comparação entre direito, economia e análise econômica do direito, tratando-o como a arte de regular o comportamento. Para ele:

\begin{abstract}
O direito é, de uma perspectiva mais objetiva, a arte de regular o comportamento humano. A economia, por sua vez, é ciência que estuda como o ser humano toma decisões e se comporta em um mundo de recursos escassos e suas consequências. A análise econômica do direito (AED), portanto, é o campo do conhecimento humano que tem por objetivo empregar os variados ferramentais teóricos e empíricos econômicos e das ciências afins para expandir a compreensão e o alcance do direito e aperfeiçoar o desenvolvimento, a aplicação e a avaliação de normas jurídicas, principalmente em relação às suas consequências (GICO JÚNIOR, 2012, p.1).
\end{abstract}

Mesmo para o leigo, com efeito, a economia está relacionada à ideia de mercado, juros, alta do dólar, queda da bolsa de valores, inflação ou ausência dela, tributação, alíquota, ajuste fiscal, crescimento, recessão, queda e aumento de emprego, importação, exportação,

\footnotetext{
${ }^{3}$ Em 1981, nos Estados Unidos da América, o caso Grimshaw v. Ford Motor Co. causou comoção geral. A empresa FORD produziu automóvel urbano que apresentava design original, em forma de pintainho. Um dos exemplares do veículo explodiu, após colisão com um obstáculo, provocando a morte do proprietário e ferimentos graves nos demais passageiros. Ao apurar as causas da explosão do veículo descobriu-se que a posição do tanque de combustível violava as regras de segurança. Constatou-se, também, que esse fato era conhecido pela FORD, que tinha encomendado estudo sobre o problema e apuração do custo para resolvê-lo. A solução apresentada implicava alterar o design do veículo. Mas, a FORD preferiu manter o design original e assumir o risco de vir a ser processada pelos eventuais lesados e condenada em indenizações em sede de responsabilidade civil. A FORD, em juízo, afirmou que preferia pagar eventuais indenizações a alterar o design, pois os lucros seriam sempre superiores às eventuais indenizações!
} 
produto interno bruto, lucro empresarial, falências de empresas, dentre outras palavras e expressões. Assim, ainda segundo Ivo Gico Jr., não são consideradas econômicas perguntas como:

\begin{abstract}
Por que estupradores costumam atacar entre $5 \mathrm{~h}$ e $8 \mathrm{~h}$ e 30 minutos. da manhã ou à noite? Por que os quintais de locais comerciais são geralmente sujos, enquanto as fachadas normalmente são limpas? Por que está cada vez mais difícil convencer os Tribunais Superiores de que uma dada questão foi efetivamente prequestionada? Por que, em Brasília, os motoristas param para que um pedestre atravesse na faixa, mas em outros locais do Brasil isso não ocorre? Por que os advogados passaram a juntar cópia integral dos autos para instruir um agravo de instrumento quando a lei pede apenas algumas peças específicas? Por que o governo costuma liberar medidas tributárias ou fiscais impopulares durante recessos e feriados, como o Natal? Por que o número de divórcios aumentou substancialmente nas últimas décadas Por que existem várias línguas? (GICO JÚNIOR ,2012, p. 12/13).
\end{abstract}

Em outras palavras, toda escolha ou tomada de decisão implica análise econômica (GICO JÚNIOR, 2012, p.13). Com efeito, em regra, a tomada de decisão, além do conteúdo econômico, possui aspectos políticos. Daí a importância de se estudar esse entrelaçamento, voltando a interpretação aos direitos coletivos, entendendo-os como capazes de lhes impor limites. Isso para dizer que não pode haver direitos absolutos, ainda mais no campo econômico.

Sob outro ângulo, a ciência da economia é vista sob perspectivas distintas por seus estudiosos. Segundo Natalino $\mathrm{Irti}^{4}$ :

(...) o naturalismo, tendo por base a imutabilidade das "leis econômicas", rejeita as lutas políticas, o mutável fluxo de opiniões, o instável acontecer do direito. Ele é por sua índole, antipolítico e antijurídico: e, portanto, cria e preza a zona "neutra", "técnica", "independente", onde silenciam todos os conflitos e imperam somente as "leis do mercado (...)" (IRTI, 2015, p.14).

Em contrapartida, os opositores ao pensamento naturalista vislumbram uma inseparável conexão entre direito e economia. De fato, não se pode pensar em direito e economia de forma isolada. Além disso, referidas ciências também estão interligadas à política e à história, bastando lembrar alguns institutos jurídicos como a propriedade privada, a permuta, a compra e venda, a alienação fiduciária e o aval, todos com grande repercussão na economia e alterados ou adaptados ao longo do tempo.

Certamente que de acordo com o paradigma de Estado adotado pode haver maior ou menor participação do poder político na economia, que possui estreita ligação com o poder

\footnotetext{
${ }^{4}$ Professor Emérito da Universitá di Roma "La Sapienza”. Acadêmico dos Linces (Lincei).
} 
econômico, este, por sua vez, implicando titularidade de patrimônio, domínio de propriedades imobiliárias e empresas. É sabido que os Estados autoritários ou totalitários centralizam a economia e os Estados liberais a delegam ao setor privado.

No paradigma democrático, tomando por exemplo o brasileiro, a par do artigo $3^{\circ}$, da Constituição Federal, deverá suceder a harmonização entre política e economia para que se atinjam os objetivos fundamentais da República afim de se construir uma sociedade livre, justa e solidária, garantir o desenvolvimento nacional, erradicar a pobreza e a marginalização, reduzir as desigualdades sociais e regionais e promover o bem de todos sem preconceito.

$\mathrm{O}$ acesso à propriedade se coloca, evidentemente, como vetor desses objetivos fundamentais, situada como bem fundamental, muito embora não se ignore a advertência de Alexandre Morais da Rosa:

\begin{abstract}
A magnitude das questões econômicas no mundo atual implica no estabelecimento de novas relações entre campos até então complementares. Direito e Economia, como campos autônomos, sempre dialogaram desde seus pressupostos e características, especificamente nos pontos em que havia demanda recíproca. Entretanto, atualmente, a situação se modificou. Não só por demandas mais regulares, mas fundamentalmente porque há uma inescondível proeminência economicista em face do discurso jurídico. Dito diretamente: o Direito foi transformado em instrumento econômico diante da mundialização do neoliberalismo. (MORAIS DA ROSA, 2015, online)
\end{abstract}

\title{
3. DIREITO CIVIL: ANÁLISE ECONÔMICA E PROPRIEDADE PRIVADA
}

A propriedade privada, para muitos, tem origem nos textos bíblicos do Antigo Testamento, Gênesis, XIII, 15: “Crescei e multiplicai-vos e enchei a terra e sujeitai-a”.

Isabel Vaz destaca três teorias mais importantes sobre a origem da propriedade privada:

\footnotetext{
Uma encontra na razão natural e na revelação divina a explicação para o direito de propriedade. Sublinhamos o pensamento de John Locke, para quem a propriedade compreendia a própria vida, a liberdade, os bens. O trabalho empregado pelo homem para modificar a Natureza assegurava-lhe um direito incontestável de propriedade. (...) Uma segunda corrente explicava o direito de propriedade segundo as crenças religiosas dos romanos e dos gregos antigos. As pessoas, ao morrerem, tinham um direito sagrado à sepultura. Cada família cultuava seus mortos, sepultados em locais sagrados, dos quais as almas se tornavam proprietárias, venerados como deuses, deuses-lares e outras denominações. (...) A teoria materialista elaborada por Engels, calcada no pensamento de Marx, parte do pressuposto de que, desde as épocas mais remotas, os homens possuíam tudo em comum: objetos caseiros, armas e lavouras (...) (VAZ, 1993, p. 617).
} 
A ideia de propriedade e sua relação com o homem variou ao longo da história da humanidade, como se viu. A relação hoje conhecida e vivida não é a mesma da antiguidade. Segundo Fustel de Coulanges existiram raças que nunca chegaram a instituir a propriedade privada. Para os germanos, as terras não tinham um dono específico e havia propriedade apenas da colheita. Já a Grécia e a Itália sempre reconheceram a propriedade privada e sempre tiveram como seu fundamento a religião, a família e a propriedade (COULANGES, 2011, p. 78-79).

A propriedade privada imobiliária, por sua vez, sempre teve tratamento especial no direito, sendo um dos motivos a sua natureza econômica, notadamente pela implicação do poder econômico e social na sua detenção. Contudo, a definição de propriedade modificou-se ao longo do tempo eis que o tratamento dado à propriedade no direito romano não é o mesmo na idade média - na qual floresceu feudal e absoluta - muito menos no período pós Revolução Francesa.

Essa diferença de tratamento num dos períodos mais críticos da história da humanidade fica evidenciada nas palavras de Jefferson Carús Guedes:

A decadência do Império Romano e o avanço da ocupação de seus domínios pelos
povos nórdicos, entre os séculos V e IX, Alta Idade Média, produziram severas
modificações no direito, diluindo a centralização forçada por Roma, substituída por
governos locais, sob regras principalmente de direito costumeiro. Expande-se o
campesinato livre 5 , sob o regime de apropriação das terras (GUEDES, 2004, p. 100).

A par desse registro, se pode extrair que os acontecimentos históricos repercutem diretamente no ordenamento jurídico, na economia, na política e na regulamentação da propriedade. E que a propriedade é uma das formas de concretização do poder econômico, pois quem é titular de patrimônio também exerce certo controle sobre os demais membros da coletividade. Também, não se pode olvidar que há uma área de confluência entre poder econômico e poder político. Na verdade, o poder econômico influencia o poder político, fazendo pressão sobre seus titulares no período eleitoral, de disputa, e após a sua aquisição, no exercício do mandato.

Não sem razão há regras que buscam conter a influência do poder econômico sobre o poder político, concretizadas na legislação eleitoral, embora pouco eficientes sem a adequada compreensão de sua função e o convencimento dos cidadãos eleitores de que são essenciais

\footnotetext{
${ }^{5}$ Segundo Jefferson Carús Guedes, no sistema campesinato, embora o camponês fosse "proprietário" de terras, subordinava-se ao "Senhor Feudal” a quem devia tributos e prestações pessoais (2004, p. 100).
} 
para a saúde da democracia.

Celso Furtado, a respeito, em obra longeva e atual, escreveu sobre a relação entre poder econômico e político criticando-a fortemente:

\begin{abstract}
(...) A atuação crescente do Estado no campo dos investimentos, conjugada àquela ineficiência, criou condições propícias à apropriação ilícita de capital à custa do povo. Os grandes contratos de obras públicas passaram a ser fonte corrente de acumulação rápida de fortunas dentro e fora do Governo. (...) aí estão os supostos representantes do povo eleitos pelos empreiteiros de obras públicas, aí está a aliança da máquina feudal com as verbas orçamentárias produzindo parlamentares, que somente poderão sobreviver se forem instrumentos dóceis de seus financiadores (1962, p. 15).
\end{abstract}

Por sua vez, o poder político contém elemento central que é o poder ideológico. Sendo que o titular do poder ideológico pode ser um aristocrata, um intelectual ou um líder carismático. A ideologia do titular do poder político repercute no ordenamento jurídico, na política econômica e até mesmo no tratamento dado ao direito de propriedade.

Segundo Isabel Vaz, “(...) em sentido amplo, a política econômica pode ser considerada como um conjunto de ações adequadas dirigidas racionalmente para a obtenção de determinados resultados de natureza econômica em uma comunidade (...)." (VAZ, 1993, p. 195). A política econômica objetiva a reestruturação, o desenvolvimento ou crescimento da economia dependendo do estágio em que esta se encontra e a partir de escolhas ideológicas dos gestores e legisladores.

Basta ver que a propriedade nos países socialistas, inspirados no antigo modelo soviético, que por sua vez, teve motivação nas ideias de Karl Max, tem como titulares o Estado e de forma subsidiária as organizações sociais e as cooperativas (VAZ, 1993, p. 529). Nos países de modelos econômicos liberais o sentido da propriedade privada recebeu influência de Locke, inspirando os autores da Constituição dos Estados Unidos de 1787, embora a Constituição americana originariamente não contivesse referência à propriedade. Somente em 1791, com a aprovação da $14^{a}$ emenda, “(...) reuniu-se em um mesmo dispositivo mecanismos destinados à proteção da 'vida', da 'liberdade' e da 'propriedade', exatamente nesta ordem (...).”(VAZ, 1993, p. 547).

É dessa autora análise acurada sobre a inserção da propriedade na Constituição americana, completamente liberal, como se sabe:

Tratava-se de limitações à atuação dos poderes públicos, de natureza impeditiva. Não eram restrições ou limitações (no caso da propriedade) às prerrogativas do 
titular do direito, mas de obstáculos dirigidos ao estado, cuja ação, por desapropriação, somente poderia exercer-se de acordo com os processos estabelecidos, da mesma forma que os particulares (VAZ, 1993, p. 547-548).

Percebe-se que a regulamentação foi feita para restringir o poder do Estado em relação à propriedade privada e não o poder de seu titular, povo, em relação à mesma. Certamente que nos Estados cujo modelo é liberal a propriedade está centrada nas mãos dos particulares, mas nem aí se pode admitir a propriedade com serventia exclusivamente privada. Que dirá no paradigma constitucional brasileiro!

\subsection{A evolução do direito de propriedade no Brasil: do indivíduo ao coletivo}

Em linhas gerais, pode-se dizer que a Revolução Francesa marcou a transformação do modelo absolutista para o liberal. Tempos adiante, após a segunda guerra mundial, em nova onda, aquele que superara o liberalismo, o Estado Social, cedeu passagem para o paradigma de Estado Democrático de Direito.

No Brasil, com a queda da ditadura militar e a redemocratização, ainda que décadas tardias, possibilitou-se a instauração de uma nova ordem constitucional em 1988. A mudança de regime repercutiu diretamente nas normas jurídicas internas do país tanto nos aspectos econômicos como sociais.

Em relação ao direito de propriedade, em maior ou menor extensão, é importante enfatizar que este sempre recebeu proteção explícita no âmbito constitucional desde a instauração da República, embora vá florescer como garantia de bem estar apenas nos períodos democráticos.

A primeira Constituição da República, de 1891, no artigo 72, §17, tratava do direito de propriedade sob perspectiva liberal, determinando que se mantivesse "em toda a sua plenitude".

Posteriormente, a Constituição democrática de 1934, no artigo 113, item 17, também se garantiu o direito de propriedade, mas constando expressamente que seu exercício não poderia se dar contra o interesse social ou coletivo - espécie de embrião em avançado estado de formação do direito social que se configurou em 1988.

O retrocesso democrático do período não retirou da Constituição do Estado Novo, de 1937, a disposição sobre o direito de propriedade, como se lê no artigo 122, item 14, mas chegou a ser suspenso com o Decreto $\mathrm{n}^{\circ} 10.358$, de 31 de agosto de 1942, que declarou guerra 
no território nacional.

A Constituição democrática de 1946, já no pós-guerra, refundou o direito de propriedade e inovou ao fazer referência ao seu aspecto social, conforme artigos $141, \S 6^{\circ} \mathrm{e}$ 147, estabelecendo que "o uso da propriedade será condicionado ao bem-estar social”.

A Constituição de 1967 , no artigo 157 , III, $\$ 1^{\circ}$, tratou da propriedade e de sua função social, em plena ditadura militar. Na mesma linha se encaminhou a Emenda Constitucional n. 1, de 17 de outubro de 1969, que manteve a Constituição de 1967 em sua maior parte, inclusive no que dizia respeito à proteção ao direito de propriedade, como se tem do artigo 153 e, no título que tratava da ordem econômica e social, artigo 160, III, fazendo constar expressamente a função social da propriedade, surpreendentemente.

De fato, a nova ordem inaugurada com a Constituição de 1988, repetindo as Constituições anteriores, consolidou o direito de propriedade como fundamental e submetido à sua função social, como se tem do caput artigo $5^{\circ}$ e do seu inciso XXIII, desvestindo-a do caráter meramente patrimonial individual, dando-lhe a feição também de princípio fundamental da ordem econômica, a par do artigo 170, inciso III, seja urbana (artigo 182, § $2^{\circ}$ ) ou rural (artigos 184 e 186).

No plano infraconstitucional, a legislação acompanhou os paradigmas estabelecidos nas Constituições, reflexos de seu tempo histórico. O Código Civil de 1916, por exemplo, dispôs sobre a propriedade no artigo 524 e seguintes, logicamente sob a perspectiva do Estado Liberal $^{6}$. Aliás, tinha como pilares a propriedade, a família e o contrato, inspirado que era no Código Civil napoleônico de 1804.

O atual Código Civil trata da propriedade no artigo 1.228 também em perspectiva liberal $^{7}$, similar à do Código antecessor. Contudo, o $\$ 1^{\circ}$ do artigo 1.228 compatibiliza-se com a norma do artigo $5^{\circ}$, XXII, da Constituição Federal quando prevê que "o direito de propriedade deve ser exercido em consonância com as suas finalidades econômicas e sociais e de modo que sejam preservados, de conformidade com o estabelecido em lei especial, a flora, a fauna, as belezas naturais, o equilíbrio ecológico e o patrimônio histórico e artístico, bem como evitada a poluição do ar e das águas”.

Desse modo, a análise do direito de propriedade ao longo do tempo permite constatar que é um direito real, mas não absoluto, notadamente coletivo, eis que só é garantido a partir

\footnotetext{
${ }^{6}$ Art. 524. A lei assegura ao proprietário o direito de usar, gozar e dispor de seus bens, e de reavê-los do poder de quem quer injustamente os possua.

${ }^{7}$ Art. 1.228. O proprietário tem a faculdade de usar, gozar e dispor da coisa, e o direito de reavê-la do poder de quem quer que injustamente a possua ou detenha.
} 
da função social que deve desempenhar, atendendo ditames de ordem econômica, ambiental, urbana, cultural dentre outros.

Tratam-se de restrições impostas pela norma constitucional, buscando compatibilizar direitos. À primeira vista, nesse diapasão, poderia parecer que a função social da propriedade e a ordem econômica fossem temas conflitantes, mas somente revelam as faces de uma mesma moeda. Ou seja, nenhuma ordem econômica pode conviver com o direito absoluto de propriedade sem que se lhe dê a destinação social para contemplar os menos favorecidos e as coletividades em geral.

Noutro ângulo, é indiscutível que toda atividade econômica tem um viés social, ainda que indiretamente. Por isso, a propriedade que é destinada à atividade econômica urbana ou rural pode visar lucros, mas sem desobedecer a normas ambientais, por exemplo. Ainda que vise lucro, fomenta a economia, gera empregos e pagamento de impostos revertidos para a população em serviços de saúde, educação, segurança e, por que não, em forma de políticas públicas para inclusão dos mais necessitados.

A rigor, com a Constituição de 1988 identifica-se o regime jurídico do direito fundamental de propriedade, classificando-o de coletivo por excelência, defensável na via judicial porquanto capaz de conferir mínimo existencial. Em especial o de moradia, encartado diretamente no caput do artigo $6^{\circ}$ como direito social.

Salomão Ismail Filho destaca o conceito dinâmico de mínimo existencial, em prol da dignidade, afirmando que a ideia é possibilitar segurança básica, mediante proteção da integridade física e psíquica em todas as suas dimensões:

De fato, o mínimo existencial não trata apenas de garantir ao ser humano um "mínimo vital", mas um mínimo de qualidade de vida, o qual lhe permita viver com dignidade, tendo a oportunidade de exercer a sua liberdade no plano individual (perante si mesmo) e social (perante a comunidade onde se encontra inserido). (FILHO, 2016, online)

A propósito, as políticas públicas no campo do direito de propriedade devem buscar a efetivação do direito humano fundamental de moradia, abrigo e identidade, viabilizador de mínimo existencial que proteja a dignidade de grupos vulneráveis social e economicamente.

O acesso a esse mínimo não deve, necessariamente, cuidar de conferir apenas patrimônio imobiliário, como se se pretendesse indenizar com a transferência da titularidade. O que se objetiva, $a b$ ovo é o mínimo à posse, às condições de permanência e de desenvolvimento na propriedade. Logicamente, sem a destacar do objetivo central de se 
chegar ao máximo, com acesso aos bens materiais garantidos para todos, sem favores ou esmolas.

Certamente que o reconhecimento do direito social, coletivo, a ser viabilizado por políticas públicas construídas com e para esses grupos vulneráveis, não podem ficar ao sabor dos interesses de grupos ideológicos localizados. Daí a necessidade de se relembrar o papel crucial a ser desempenhado pelo Judiciário, na hipótese de omissão dos poderes públicos.

Por isso, na defesa de minorias políticas, em onda contramajoritária à visão economicista, “o Poder Judiciário dispõe de competência para exercer, no caso concreto, controle de legitimidade sobre a omissão do Estado na implementação de políticas públicas cuja efetivação lhe incumbe por efeito de expressa determinação constitucional."8.

\subsection{Controle judicial para densificação dos preceitos fundamentais atinentes ao direito de propriedade}

A democratização do acesso à propriedade, fundamentalmente para garantir moradia, direito social precitado, verdadeiro preceito fundamental, necessita da adoção de políticas públicas com tal objetivo, como dito alhures.

$\mathrm{Na}$ sua falta, além da possibilidade de manejo das ações civis públicas pelo Ministério Público, consoante determina o inciso III do artigo 129 da Constituição, cabe o controle concentrado dessa omissão, por meio da ação direta específica, tal como realçou o Ministro Celso de Mello no julgamento da ADI 1.458, isto já em 1996, quando tratava da recusa do Poder Público em adotar salário mínimo compatível com a dignidade humana, outro direito social bastante maltratado:

\footnotetext{
Se o Estado deixa de adotar as medidas necessárias à realização concreta dos preceitos da Constituição, em ordem a torna-los efetivos, operantes e exequíveis, abstendo-se, em consequência, de cumprir o dever de prestação que a Constituição lhe impôs, incidirá em violação negativa do texto constitucional. Desse 'non facere' ou 'non praestare', resultará a inconstitucionalidade por omissão, que pode ser total, quando é nenhuma a providência adotada, ou é parcial, quando é insuficiente a medida efetivada pelo Poder público. (BRASIL, 1996, online).
}

O cariz social do direito em tela, que exige ação política para implementação das

\footnotetext{
${ }^{8}$ BRASIL. Supremo Tribunal Federal. Arguição de Descumprimento de Preceito Fundamental $\mathrm{n}^{\circ}$ 347-DF. Relator Ministro Marco Aurelio Melo. Data da publicação: 19 de fev. 2016, Diário do Judiciário Eletrônico de 18 fev. 2016.. Disponível em: <http://redir.stf.jus.br/paginadorpub/paginador.jsp?docTP=TP\&docID=10300665>. Acesso em: 08 mai. 2017.
} 
medidas necessárias, traz a política pública (ou a falta dela) para a cena judicial, eis que "Nada mais nocivo, perigoso e ilegítimo do que elaborar uma Constituição sem a vontade de fazê-la cumprir integralmente ou, então, de apenas executá-la com o propósito subalterno de torna-la aplicável somente nos pontos em que se mostrarem convenientes aos desígnios dos governantes, em detrimento dos interesses maiores dos cidadãos."9

O direito à moradia, além do quanto assentado na Constituição brasileira, também se encontra protegido em inúmeros documentos e tratados internacionais, como a Declaração Universal dos Direitos Humanos de 1948, artigo 25, o Pacto Internacional de Direitos Sociais, Econômicos e Culturais de 1966, artigo 11, no Pacto de San José da Costa Rica, de 1969, dentre muitos (OSÓRIO, 2006).

André de Carvalho Ramos, comentando os direitos sociais nos tratados internacionais, em destaque do artigo 11 do Pacto Internacional de Direitos Sociais, Econômicos e Culturais, classificam-nos de "direito à esperança". Como diz:

(...) são aqueles direitos que asseguram uma vida material digna, exigindo prestações positivas do Estado, caso o indivíduo as necessite. O Pacto Internacional dos Direitos Econômicos, Sociais e Culturais, ora em comento, estabelece o direito de toda pessoa a um nível de vida adequado para si próprio e para sua família, o que deve incluir alimentação, moradia e vestimenta, assim como a melhoria contínua de suas condições de vida (mencionado no artigo 11 como verdadeiro direito à esperança). (RAMOS, 2016, p. 138-139)

O quadrante ampliado da internacionalidade do direito, configurando a supraestatalidade da matéria que pode ser controlada por Cortes Internacionais, acende o alerta para a necessária viragem hermenêutica na interpretação da matéria pelos tribunais brasileiros, também com vistas à responsabilidade internacional objetiva do Estado infrator.

Reconhecendo a "era da Justiça Econômica", Alexandre Morais da Rosa denuncia o formato e o impacto das decisões do Supremo Tribunal Federal aplicando o método de análise econômica do direito, preocupado com as "externalidades" ao invés de fazê-lo a par da "normatividade", em fundamentos ocultos de difícil controle (MORAIS DA ROSA, 2016, online). Para ele, a leitura dos direitos sociais, pelas lentes economicistas, dificulta implantação do Estado Democrático de Direito. E isso se dá porque “(...) há uma inescondível

\footnotetext{
${ }^{9}$ BRASIL. Supremo Tribunal Federal. Arguição de Descumprimento de Preceito Fundamental $\mathrm{n}^{\circ}$ 347-DF. Relator Ministro Marco Aurelio Melo. Data da publicação: 19 de fev. 2016, Diário do Judiciário Eletrônico de 18 fev. 2016.. 20 Disponível <http://redir.stf.jus.br/paginadorpub/paginador.jsp?docTP=TP\&docID=10300665>. Acesso em: 08 mai. 2017.
} 
proeminência economicista em face do discurso jurídico”. Ou seja, “(...) o Direito foi transformado em instrumento econômico diante da mundialização do neoliberalismo" (MORAIS DA ROSA, 2016, online).

Nesse quadrante, a oferta fundamental para a intepretação e aplicação do direito social em voga passa pela compreensão da responsabilidade do Estado pela consolidação da cidadania e da aplicabilidade imediata dos direitos fundamentais, na linha do parágrafo primeiro, do artigo $5^{\circ}$, da Constituição brasileira, corroborada pelos variados tratados internacionais firmados pelo Brasil (PIOVESAN, 2014).

Como anota Flávia Piovesan, apoiada na lição de Canotilho,

\footnotetext{
“(...) ao Judiciário compete: a) interpretar os preceitos constitucionais consagradores de direitos fundamentais, na sua aplicação em casos concretos, de acordo com o princípio da efetividade ótima; e b) densificar os preceitos constitucionais consagradores de direitos fundamentais, de forma a possibilitar a sua aplicação imediata, no caso de ausência de leis concretizadoras. (PIOVESAN, 2014, p. 502)
}

Com esse norte, o controle da omissão de políticas públicas capazes de viabilizar, imediatamente, o acesso à moradia como parte do direito de propriedade, não pode se apoiar em premissas falsas, rendidas a argumentos de utilidade e economicidade.

\section{CONCLUSÃO}

A análise econômica do direito é método interpretativo utilizado largamente nos modelos liberais, mas, no Brasil, exige a necessária refração pelo paradigma de Estado Democrático, para que se solidifiquem os fundamentos da República rumo à justiça social.

O direito à propriedade se coloca como um dos vetores da justiça social, especialmente para que se garantia moradia e dignidade aos mais necessitados, bens da vida que não podem ser alheados.

O constitucionalismo brasileiro sempre contemplou o direito de propriedade, embora nos períodos democráticos é que ganhou perfil social, desvestindo-se do caráter patrimonial individual sagrado.

A Constituição brasileira de 1988 definiu o regime jurídico do direito em tela, classificando-o de coletivo por natureza, capaz de conferir mínimo existencial, impondo dever ao Estado de garanti-lo por meio de políticas públicas destinadas aos menos favorecidos. Tal direito também encontra abrigo em tratados internacionais firmados pelo Brasil 
A ausência de políticas públicas viabilizadoras do direito de propriedade, no formato aqui trabalhado, deve ser controlada pelo Judiciário local objetivando sua garantia, sem embargos da atuação das cortes internacionais, ante a responsabilidade objetiva do Estado infrator.

Por fim, a intepretação e aplicação do direito social passa pela compreensão da responsabilidade do Estado em garantir mínimos existenciais para consolidação da cidadania, possibilitando sua aplicação imediata, renunciando às externalidades para fazer valer a normatividade constitucional.

\section{REFERÊNCIAS}

BRASIL. Supremo Tribunal Federal. Arguição de Descumprimento de Preceito Fundamental no 347-DF. Relator Ministro Marco Aurelio Melo. Data da publicação: 19 de fev. 2016,

Diário do Judiciário Eletrônico de 18 fev. 2016.. Disponível em: $<$ http://redir.stf.jus.br/paginadorpub/paginador.jsp?docTP=TP\&docID=10300665>. Acesso em: 08 mai. 2017.

BRASIL. Supremo Tribunal Federal. Ação Direta de Inconstitucionalidade $n^{\circ} 1458$-DF. Relator Ministro Celso de Mello. Data da publicação: 20 de set. 1996, Diário do Judiciário da União de 20 set. 1996, p. 34.531. Disponível em: <

http://redir.stf.jus.br/paginadorpub/paginador.jsp?docTP=AC\&docID=347068>. Acesso em: 08 mai. 2017.

CAENEGEM, Raoul .Charles.Van. Uma introdução histórica ao direito privado. $2^{a}$ ed. São Paulo: Martins Fontes, 2000.

COULANGES, Fustel de. Cidade antiga. 2 ed. Revista dos Tribunais: São Paulo, 2011.

FERREIRA, Sérgio de Abreu. O Princípio da Autonomia Privada e a Função Social da Empresa. In: FIÚZA, César; FREIRE DE SÁ, Maria de Fátima; NAVES, Bruno Torquato de Oliveira (Coordes.). Direito civil. Princípios Jurídicos no Direito Privado. Atualidades III. Belo Horizonte: Del Rey, 2009.

FILHO, Salomão. Ismail. Mínimo existencial: um conceito dinâmico em prol da dignidade humana. Consultor Jurídico. São Paulo: CONJUR, 05 dez. 2016. Disponível em: <http://www.conjur.com.br/2016-dez-05/mp-debate-minimo-existencial-conceito-dinamicoprol-dignidade-humana>. Acesso em 06 mai. 2017.

FLORES FILHO, Edgar Gaston Jacobs. O Princípio da Eficiência e a Justiça: análise econômica da acessão inversa no direito privado brasileiro. In: FIÚZA, César; FREIRE DE SÁ, Maria de Fátima; NAVES, Bruno Torquato de Oliveira (Coordes.). Direito civil. Princípios Jurídicos no Direito Privado. Atualidades III. Belo Horizonte: Del Rey, 2009.

FURTADO, Celso. A pré-revolução brasileira. Fundo de Cultura: Rio de Janeiro,1962. 
GICO JÚNIOR, Ivo. Introdução ao Direito e Economia. In: TIMM, Luciano Benetti, organizador. Direito e Economia no Brasil. São Paulo: Atlas, 2012.

GUEDES, Jefferson Carús. Função Social das "Propriedades": da Funcionalidade Primitiva ao Conceito Atual de Função Social. Revista de Direito Social. Porto Alegre: Fonte do Direito, ano 4, p. 97-120, jul./set. 2004.

IRTI, Natalino. Direito e Economia. Revista de Direito Privado. São Paulo: Revista dos Tribunais, ano 16, RDPtiv. v. 62, p. 13-30, abr./jun. 2015.

MAIA JÚNIOR, Mairan Gonçalves. O conteúdo econômico e jurídico do pacto antenupcial e o planejamento patrimonial familiar. Revista de Direito Privado. São Paulo: Revista dos Tribunais, ano 16, v. 62, p. 197-219, abr./jun. 2015.

MORAIS DA ROSA, Alexandre. O giro econômico da hermenêutica do Supremo Tribunal Federal já chegou. Consultor Jurídico. São Paulo: CONJUR, 07 fev. 2015. Disponível em: < http://www.conjur.com.br/2015-fev-07/diario-classe-giro-economico-hermeneutica-supremochegou>. Acesso em 02 mai. 2017.

MUKAI, Sylvio Toshiro. Direito à moradia e a Concessão Especial para fins de moradia. Fórum de Direito Urbano e Ambiental - FDUA. Belo Horizonte: Fórum, ano 1, n. 1, p. 79-82, jan./fev. 2002.

NATAlinO, Irti. Direito e Economia. Revista de Direito Privado. São Paulo: Revista dos Tribunais, ano 16, v. 62, p. 13-30, abr./jun. 2015.

OLIVEIRA, Wilson de. Identificação do Conteúdo Econômico no Anteprojeto do Código Civil Brasileiro (1972). Universidade Federal de Minas Gerais. Belo Horizonte: UFMG. n, 1, p. 56-89. 1975.

OSÓRIO, Letícia Marques. Direito à moradia adequada na América Latina. In: ALFONSIN, Betânia; FERNANDES, Edésio (Org.). Direito à moradia e segurança da posse no Estatuto da Cidade: diretrizes, instrumentos e processos de gestão. Belo Horizonte: Fórum, 2006.

PIMENTA, Eduardo Goulart. Princípios Fundamentais do Direito Privado da Propriedade Industrial. In: FIÚZA, César; FREIRE DE SÁ, Maria de Fátima; NAVES, Bruno Torquato de Oliveira (Coordes.). Direito civil. Princípios Jurídicos no Direito Privado. Atualidades III. Belo Horizonte: Del Rey, 2009.

PIOVESAN, Flávia. Temas de direitos humanos. $7^{\text {a }}$ ed., São Paulo: Saraiva, 2014.

RAMOS, André de Carvalho. Teoria geral dos direitos humanos na ordem internacional. $6^{\mathrm{a}}$ ed. São Paulo: Saraiva, 2016.

SOARES, Sávio de Aguiar. Direito de propriedade privada e sua função social: estudo sob a perspectiva civil-constitucional. In: FIÚZA, César; FREIRE DE SÁ, Maria de Fátima; NAVES, Bruno Torquato de Oliveira (Coordes.). Direito civil. Princípios Jurídicos no 
Direito Privado. Atualidades III. Belo Horizonte: Del Rey, 2009.

VAZ, Isabel. Direito econômico das propriedades. 2 ed. Rio de Janeiro: Forense, 1993.

VERA, Flávia Santinoni. A Análise Econômica da Propriedade. In: TIMM, Luciano Benetti, organizador. Direito e Economia no Brasil. São Paulo: Atlas, 2012. 